\title{
Immunology of breast milk
}

\author{
Patricia Palmeira ${ }^{1 *}$, Magda Carneiro-Sampaio ${ }^{2}$ \\ 'PhD - Scientific Researcher, Laboratory of Medical Investigation (LIM-36), Department of Pediatrics, Hospital das Clínicas, Faculdade de Medicina, Universidade de São Paulo (HC-FMUSP), São Paulo, SP, Brazil \\ ${ }^{2} \mathrm{MD}$, PhD - Full Professor, Department of Pediatrics, FMUSP, São Paulo, SP, Brazil
}

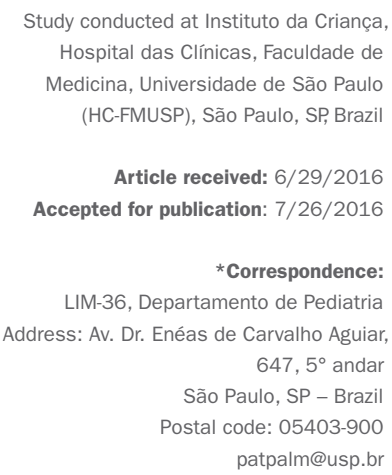

Study conducted at Instituto da Criança, Hospital das Clínicas, Faculdade de Medicina, Universidade de São Paulo (HC-FMUSP), São Paulo, SP, Brazil

Article received: $6 / 29 / 2016$ Accepted for publication: $7 / 26 / 2016$

*Correspondence:

LIM-36, Departamento de Pediatria Address: Av. Dr. Enéas de Carvalho Aguiar, $647,5^{\circ}$ andar São Paulo, SP - Brazil Postal code: 05403-900 patpalm@usp.br

http://dx.doi.org/10.1590/1806-9282.62.06.584

\section{SUMmarY}

In the critical phase of immunological immaturity of the newborn, particularly for the immune system of mucous membranes, infants receive large amounts of bioactive components through colostrum and breast milk. Colostrum is the most potent natural immune booster known to science. Breastfeeding protects infants against infections mainly via secretory $\operatorname{IgA}(\mathrm{S} I g \mathrm{~A})$ antibodies, but also via other various bioactive factors. It is striking that the defense factors of human milk function without causing inflammation; some components are even anti-inflammatory. Protection against infections has been well evidenced during lactation against, e.g., acute and prolonged diarrhea, respiratory tract infections, including otitis media, urinary tract infection, neonatal septicemia, and necrotizing enterocolitis. The milk's immunity content changes over time. In the early stages of lactation, IgA, anti-inflammatory factors and, more likely, immunologically active cells provide additional support for the immature immune system of the neonate. After this period, breast milk continues to adapt extraordinarily to the infant's ontogeny and needs regarding immune protection and nutrition. The need to encourage breastfeeding is therefore justifiable, at least during the first 6 months of life, when the infant's secretory IgA production is insignificant.

Keywords: human milk, secretory IgA antibodies, infections, term newborn, preterm newborn.

\section{INTRODUCTION}

The neonatal period is particularly critical because after birth babies are immediately exposed to a large number of microorganisms. The high morbidity and mortality rates observed during the first months of life due to infectious diseases such as otitis media, upper and lower respiratory tract infections, gastroenteritis, sepsis, and meningitis are due, among other factors, to significant quantitative and qualitative deficiencies in various components of the immune system (Table 1 ). ${ }^{1}$ To compensate for this immunological immaturity inherent to the fetal and neonatal periods and the first months of life, nature has developed adoptive protection mechanisms provided by the mother, represented by i) the transplacental transfer of antibodies, ii) anti-infective resistance factors in the amniotic fluid, and iii) in extrauterine life, colostrum and milk. ${ }^{2}$

Colostrum (milk produced during the first days after birth), in addition to being a rich source of nutrients, contains high concentrations of various protective factors with anti-infective action, such as enzymes (lysozyme, lactoferrin etc.), immunoglobulins, cytokines, complement system components, leukocytes, oligosaccharides, nucleotides, lipids, and hormones that interact with each other and with the mucous membranes of the digestive and upper respiratory tracts of infants, providing passive immunity as well as stimulation for the development and maturation of the infant's immune system (Table 2$)^{3}$

The antimicrobial factors present in colostrum and milk have some common characteristics, such as resistance to degradation by digestive enzymes, protection of the mucosal surfaces and elimination of bacteria without initiating inflammatory reactions. ${ }^{4}$ The presence of various bioactive components in breast milk with multifunctional and anti-inflammatory properties provides wide evidence to support the recommendation of exclusive maternal breastfeeding (defined as the exclusive con- 


\section{TABLE 1 Immature components of the immune system at birth and during childhood.}

Innate immune system

Monocytes and dendritic cells: Lower expression of co-stimulatory molecules and MHC class II in response to stimulation via Toll-like receptors (TLRs); lower production of IL-12 and IFNs type I, responsible for the response against intracellular pathogens; similar or higher levels of production of pro-inflammatory cytokines and IL-23.

Neutrophils: Small reservoir of progenitor cells; inadequate chemotaxis, adhesion and migration.

Complement system: Low concentrations of various components, particularly C9; predominance for activation via alternative pathway. Natural killer cells: Lower cytolytic capacity against many types of target cells, including cells infected with herpes simplex virus and cytomegalovirus.

Adaptive immune system

High numbers of lymphocytes in the peripheral blood, both in percentages and absolute numbers, in the first years of life.

Spleen and lymph nodes: The thymus and secondary lymphoid organs grow rapidly in the first years of life, reaching their maximum size in adolescence, and then regress; spleen is already well developed at birth; the lymph nodes and lymphoid tissue associated with mucous membranes have reduced dimensions.

T cells: High proportion of naive (high expression of CD45RA and L-selectin) T cells in the early years of life; intrinsic immaturity of CD $4^{+} T$ cells, with lower capacity to perform effector functions and turn into memory cells (gradual acquisition of memory T cells throughout childhood); deviation of response to the Th2 type; limited activity of antibody-dependent cell-mediated cytotoxicity; low B cell stimulation and subsequent production of antibodies and isotype switch.

Regulatory T cells: High presence of naive Treg cells.

B cells: Predominant naive phenotype; limited repertoire of antibody production.

Antibodies: IgG levels (acquired by placental transmission) equivalent or higher than the maternal levels and catabolized during the first months; limited production of $\operatorname{lgG} 1$ and $\operatorname{lgG} 3$ (mature at about 1-2 years of age); $\operatorname{lgG} 2$ production begins after 2 years of age and matures at the end of childhood, with a low response to polysaccharide antigens; IgG4 production matures at about 3-7 years of age; low levels of serum IgA, reaching adult concentrations around 12 years of age; secretory IgA reaches half of the adult values in the second semester of life and equivalent levels to those of adults only between 2 and 4 years of age.

TABLE 2 Bioactive factors of colostrum and breast milk.

\begin{tabular}{lll} 
Soluble components & Cellular components & Microbiota \\
\hline Antibodies (especially secretory lgA $)$ & $*\left(10^{4}\right.$ to $10^{6}$ cells $/ \mathrm{mL}$ in the colostrum $)$ & $\dagger\left(8 \times 10^{4}\right.$ to $8 \times 10^{6}$ bacteria/800 $\left.\mathrm{mL} / \mathrm{day}\right)$ \\
$\begin{array}{l}\text { Free secretory component } \\
\text { Lysozyme }\end{array}$ & $\left(10^{5}\right.$ cells $/ \mathrm{mL}$ in mature milk $)$ & Main genera: \\
Lactoferrin & Neutrophils & Lactobacillus \\
Lactoperoxidase & Macrophages & Staphylococcus \\
$\kappa$-casein & $\mathrm{CD} 4^{+}$T cells & Streptococcus \\
$\alpha$-Lactoglobulin & $\mathrm{CD} 8^{+} \mathrm{T}$ cells & Enterococcus \\
Haptocorrin & $\mathrm{T} \delta$ cells & Bifidobacterium \\
Osteoprotegerin & $\mathrm{B}$ cells & Kocuria \\
sCD14 & $\mathrm{NK}$ cells & Lactococcus \\
Hormones & Epithelial cells & Leuconostoc \\
Growth factors & & Pediococcus \\
Cytokines and chemokines & & Propionibacterium \\
Lipids & & Rothia \\
Nucleic acids & Weissella \\
Oligosaccharides & \\
Antioxidant factors & & \\
\hline
\end{tabular}

* Adapted from Barros and Carneiro-Sampaio, 1984, ${ }^{65} \dagger$ adapted from Heikkilä and Saris, 2003; $;^{71} \varphi$ adapted from Fernández et al., 2013. ${ }^{73}$ 
sumption of breast milk and no other liquids or food) within one hour after birth and during the first 6 months of life for all healthy women and children. ${ }^{5}$

\section{Protein components of human MiLK}

\section{Secretory IgA antibodies}

Human milk has antibodies directed at numerous pathogens with which the mother has had contact throughout life, somehow representing an immunological memory. ${ }^{6}$ These antibodies constitute the majority of the protein content of this secretion in the first days of lactation. Antibody concentrations fall throughout lactation; however, the amount of immunoglobulins received by the child remains unchanged due to the increased milk intake. ${ }^{7} \mathrm{Al}-$ though all immunoglobulin isotypes are found in colostrum and milk, secretory IgA (SIgA) is considered the most important, both in relation to its concentration and biological properties. ${ }^{8}$ SIgA antibodies in breast milk are essential in the defense of the mucous membranes. These antibodies effectively prevent the entry of microorganisms in the tissues, they are anti-inflammatory and do not consume energy during the reaction. ${ }^{9,10}$

IgM antibodies are the second most abundant immunoglobulin in human colostrum, at concentrations of up to $2.5 \mathrm{mg} / \mathrm{mL}$. High avidity IgM antibodies reactive with viruses and bacteria may play an important role in protecting the mucosal surfaces of infants. IgG is found at low concentrations in human milk, around $0.1 \mathrm{mg} / \mathrm{mL}$ ( $10 \%$ of serum values) and, in addition to neutralizing activity, has opsonizing activity that can activate the complement system and antibody-dependent cytotoxicity, which is not thought to be strongly present on the infants' mucosal surfaces. ${ }^{2}$

SIgA is responsible for 80 to $90 \%$ of total immunoglobulins in human milk, and infants fed exclusively with breastfed receive around $0.3 \mathrm{~g} / \mathrm{kg} /$ day of this protein, where only around $10 \%$ is absorbed in the intestines and transferred to the bloodstream, that is, its action is fundamentally local. ${ }^{11,12}$ The role of SIgA and, to a lesser extent, SIgM is to act locally on the newborn's intestine as a first line of defense directed at foreign antigens. As a result, SIgA molecules remain active throughout the newborn's gastrointestinal tract and impact the binding of commensal or pathogenic microorganisms, toxins, viruses, and other antigenic materials, such as lipopolysaccharide (LPS), preventing their adherence and penetration into the epithelium without triggering inflammatory reactions that could be harmful to the newborn, a mechanism known as immune exclusion. High-affinity dimeric IgA and pentameric IgM antibodies transported by the
pIgR may even inactivate viruses (e.g. rotavirus and influenza) within epithelial cells and carry these pathogens and their products back into the lumen, thereby avoiding cytolytic damage to the epithelium. ${ }^{13}$ In individuals with selective IgA deficiency, SIgM antibodies are of great importance, since they constitute a compensation mechanism for the lack of SIgA in the mucous membranes, and are present at high levels in these secretions. ${ }^{14}$

Figure 1 shows an immunochemical test (Western blotting) in which IgA antibodies from the colostrum remain viable in the feces of an exclusively breastfed newborn, and, in this particular case, are able to bind to antigens originating from enteropathogenic Escherichia coli. ${ }^{15}$ This technique demonstrates that SIgA antibodies were not destroyed by digestion and that they protect the entire intestinal tract. Thus, the effect of dimeric IgA antibodies produced locally would promote the inhibition of excessive colonization of microorganisms from the mucous membrane, as well as the penetration of soluble antigens.

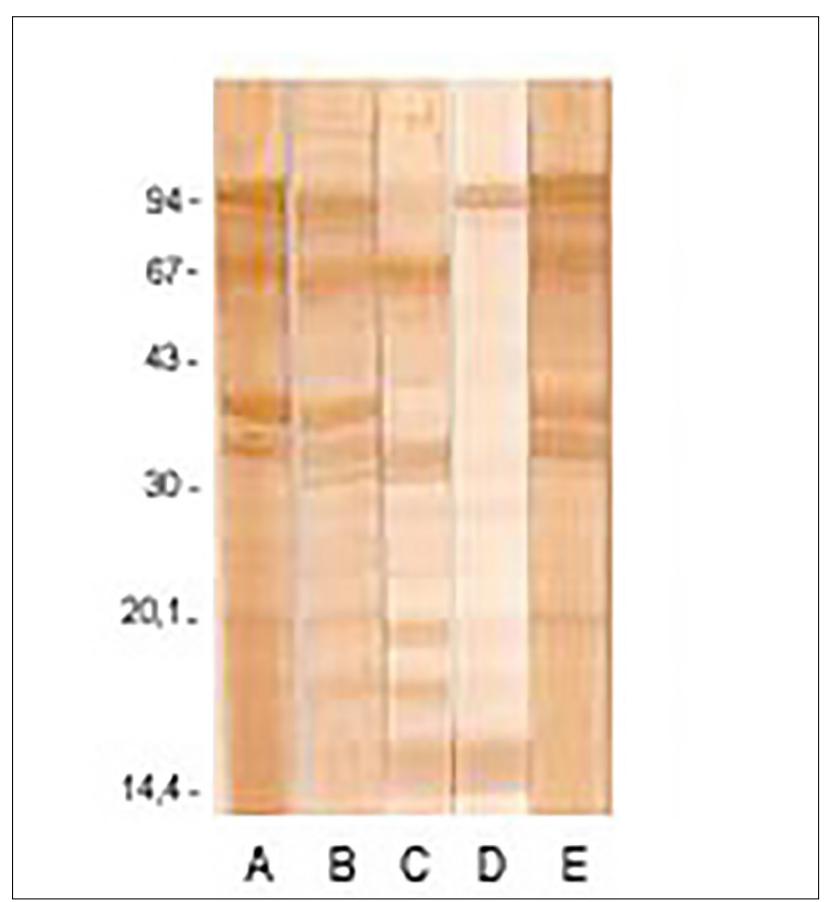

Figure 1 Western blotting reaction performed with enteropathogenic E. coli (EPEC) antigens that reacted with samples of human colostrum (samples A, B, C and E) and a stool sample from an exclusively breastfed five-day old newborn (D) (colostrum - sample E). Note that there are distinct EPEC antigen recognition patterns in the colostrum samples from different mothers (A-C). Sample D reveals that there are intact $\lg A$ antibodies in the feces of the breastfed newborn that recognize certain EPEC antigens, including intimin $(94 \mathrm{kDa})$, an important bacterial adhesin. ${ }^{15}$ 


\section{Free secretory component}

Free secretory component (SC), which is particularly abundant in breast milk, can block epithelial adhesion and therefore limit infection by enterotoxigenic Escherichia coli, ${ }^{16}$ Salmonella typhimurium, ${ }^{17}$ and pneumococcus, ${ }^{18}$ as well as inhibit the effect of bacterial toxins such as Clostridium difficile toxin $\mathrm{A} .{ }^{19}$

\section{Lysozyme and lactoferrin}

Major enzymes present in colostrum include lysozyme and lactoferrin. Lysozyme is an enzyme capable of degrading the outer wall of Gram-positive bacteria, as it hydrolyzes $\beta-1,4$ bonds from the residues of $\mathrm{N}$-acetylmuramic acid and $\mathrm{N}$-acetylglucosamine. ${ }^{20}$ Lysozyme also has the ability to kill Gram-negative bacteria in vitro, acting synergistically with lactoferrin, which binds to the lipopolysaccharide in the outer bacterial membrane, removing it and allowing lysozyme to access and degrade the internal proteoglycan matrix of the membrane, thereby killing the bacteria. ${ }^{21}$ Lysozyme is also reported as having antiviral activity. ${ }^{22}$

SIgA and lactoferrin correspond to $26 \%$ of the protein content of breast milk, resulting in a lactoferrin concentration of approximately $1 \mathrm{~g} / \mathrm{L}$ in mature milk and 7 $\mathrm{g} / \mathrm{L}$ in colostrum. ${ }^{23}$ It has a bacteriostatic function in the intestinal mucosa of the newborn, by binding with the iron present in the child's digestive system, preventing the growth of various pathogens. In addition, it has a direct cytotoxic effect against bacteria, viruses, and fungi and carries out immunomodulatory functions, helping to limit excessive immune responses by blocking many inflammatory cytokines such as IL- $1 \beta$, IL- 6 , TNF- $\alpha$ and IL- $8^{24-26}$ while also stimulating the activity and development of the child's immune system. ${ }^{27}$ Part of lactoferrin's activity is attributed to the formation of lactoferricin, a potent cationic peptide with bactericidal activity formed during the digestion of lactoferrin. ${ }^{28}$

\section{Lactoperoxidase}

Lactoperoxidase, in the presence of hydrogen peroxide (formed in small amounts by the cells), catalyzes the oxidation of thiocyanate (present in saliva), forming hypothiocyanate that can kill both Gram-positive, ${ }^{29}$ as well as Gram-negative bacteria. ${ }^{30}$

\section{к-Casein}

$\kappa$-casein, a small subunit of casein present in breast milk, is a glycoprotein that contains charged sialic acid residues and presents inhibitory activity for adhesion by Helicobacter pylori to the human gastric mucosa by acting as a soluble receptor analogue of epithelial cell surfaces. ${ }^{31}$

\section{$\alpha$-Lactalbumin}

It has been shown that various hydrolysis products of casein and $\alpha$-lactalbumin have antimicrobial activity against E. coli, Klebsiella pneumoniae, staphylococcus, streptococcus, and C. albicans. ${ }^{32} \alpha$-Lactalbumin in human milk also has the property of binding to oleic acid and, after the release of $\mathrm{Ca}^{2+}$ ions and conformational change, it forms a compound called HAMLET (human $\alpha$-lactalbumin made lethal to tumor cells). ${ }^{33}$

\section{Haptocorrin}

It has been suggested that the haptocorrin protein present in human milk has the property of binding to vitamin B12, making it inaccessible for bacterial growth. It has been shown that both haptocorrin exposed to digestive enzymes as well as undigested haptocorrin inhibit the growth of a strain of enteropathogenic E. coli at similar levels, suggesting this protein contributes to defense against infections in breastfed children. ${ }^{34}$

\section{Osteoprotegerin}

Osteoprotegerin is found in the epithelial cells of the mammary gland and in human milk at concentrations up to 1,000 times higher than those found in human serum. ${ }^{35} \mathrm{It}$ can bind to TNF-related apoptosis-inducing ligand (TRAIL) and induce caspase-dependent apoptosis, especially in Th1 cells, which is supposed to be important to regulate the balance of Th1/Th2 in the development of the immune system in newborns. ${ }^{36}$

\section{Soluble CD14 (sCD14)}

Colostrum and breast milk contain high levels of the sCD14 molecule, exceeding the concentration found in the serum more than 20 times. ${ }^{37}$ This component affects the modulation of innate and adaptive immune responses in the intestine during bacterial colonization and thus controls homeostasis in the newborn's intestine. ${ }^{38}$

\section{HoRMONES AND GROWTH FACTORS}

Hormones and growth factors are among the bioactive components found in human milk. Some hormones may have a direct effect on breast and on milk production (insulin, steroids, prolactin), while others may contribute to the growth, differentiation, and development of various tissues in the infant. ${ }^{39}$ The various growth factors (epidermal growth factor, nerve growth factor, insulin, TGF- $\alpha$, TGF- $\beta$, relaxin and insulin-like growth factor) particularly influence the growth and development of the gastrointestinal tract but may have some effect on glucose levels and systemic growth. 
Colostrum and breast milk contain colony stimulating factors (CSF), responsible for regulating the proliferation, differentiation, and survival of milk neutrophils and macrophages, such as GM-CSF (granulocyte-macrophage colony stimulating factor), M-CSF (macrophage colony stimulating factor) and G-CSF (granulocyte-colony stimulating factor). GM-CSF, ${ }^{40} \mathrm{M}-\mathrm{CSF}^{41}$ and G-CSF have been isolated from human milk at concentrations ranging from 45 to $1551 \mathrm{pg} / \mathrm{mL},{ }^{42}$ while the plasma concentrations are significantly lower and less variable $(10.5 \pm 4.5 \mathrm{pg} / \mathrm{mL})$.

\section{Cytokines And Chemokines}

Cytokines in human milk may have an immunostimulatory or immunomodulatory effect on phagocytic cells and on lymphocytes involved in developing the specific immune response of the child, acting in the prevention of allergies and hypersensitivities. They may also target the cells of breast milk itself, promoting activation, phagocytosis stimulation and antigen presentation; inducing growth, differentiation and production of immunoglobulin by B cells; increasing thymocyte proliferation; and the suppression of IgE production. ${ }^{43}$

Certain cytokines such as IL- 6 and TNF- $\alpha$ are associated with regulating the development and functions of the mammary gland, and others, such as IL- 1 and IFN- $\gamma$, influence the production of defense agents, SIgA, or other cytokines by the mammary gland. ${ }^{44} \mathrm{IL}-10$ is an important anti-inflammatory and immunoregulatory cytokine present in high concentration in both the aqueous phase and in the lipid layer of breast milk. Like IL-10, TGF- $\beta$ (transforming growth factor- $\beta$ ) has important immunomodulatory properties, such as stimulating intestinal maturation and defense of the newborn; involvement in switching from IgM to IgA in B lymphocytes; immunoglobulin production in the mammary gland and the gastrointestinal tract of the newborn, and induction of oral tolerance. Its suppressive effect on $\mathrm{T}$ cells has been associated with a possible role in the prevention, or at least suppression of the onset of allergic diseases in breastfed infants. ${ }^{45}$

CXC chemokines, potent activators of neutrophils, are present in large quantities in breast milk, and have chemotactic activity for intraepithelial lymphocytes and play an important role in the host's defense against bacterial and viral infections. ${ }^{46-48}$

\section{LIPIDS}

The fat content of breast milk is $3-4 \mathrm{~g} / \mathrm{L}$ in colostrum and transition and mature milk, with $93-97 \%$ of lipids in the form of triglycerides. It has been demonstrated that in addition to their nutritional and development benefits, milk fats perform antimicrobial activity in the intestine of infants. ${ }^{49}$ Free fatty acids (FFAs) and monoglycerides, the digestive products of triglycerides, have a lytic effect on several viruses. ${ }^{50-52}$ FFAs also have an antiprotozoal effect, particularly against Giardia. The passive protection of breast milk may also be provided by components present in the milk fat globules, such as mucins, which can prevent the binding of pathogens in the stomach and small intestine of the infant. ${ }^{53,54}$

\section{NUCLEIC ACIDS}

Nucleotides, nucleosides, nucleic acids, and related products constitute around 15 to $20 \%$ of the non-protein nitrogen content in breast milk. In vitro and in vivo experiments suggest a variety of different functions for ingested nucleotides: increasing iron absorption; increasing the growth of Bifidobacterium; increasing the growth, development, and repair of the gastrointestinal mucosa; and increasing NK cell activity and IL-2 production. ${ }^{55}$

\section{Carbohydrates}

Carbohydrates in breast milk include lactose and oligosaccharides as the main components, as well as glycoconjugates. As with most components of breast milk, oligosaccharides are found at high concentrations in colostrum (approximately $22 \mathrm{~g} / \mathrm{L}$ ), and are less abundant in mature milk $(12 \mathrm{~g} / \mathrm{L}){ }^{56}$ The types of oligosaccharides present in the milk also change during lactation and the concentration tends to decrease during breastfeeding. ${ }^{57}$

The factor that promotes the growth of lactobacilli and bifidobacteria, which in turn inhibit the growth of pathogenic microorganisms by decreasing intestinal $\mathrm{pH}$, was originally described as bifidus factor, but currently one of the substances identified as promoting this growth is $\mathrm{N}$-acetyl-glucosamine. ${ }^{58}$ Subsequently, various oligosaccharides with similar action have been identified, but it is possible that proteins in the milk also show this prebiotic activity. ${ }^{59}$

\section{AntIOXIDANT Factors}

There are various antioxidants in human milk that can eliminate free radicals and thus limit the damage caused by oxidative stress. These compounds include $\alpha$-tocopherol, ${ }^{60} \beta$-carotene, ${ }^{61}$ cysteine, ${ }^{62}$ ascorbic acid, ${ }^{61}$ catalase, and glutathione peroxidase. ${ }^{63}$ In vitro studies have demonstrated that breast milk degrades naturally-occurring hydrogen peroxide, as well as that produced by neutrophils, possibly due to their catalase content. ${ }^{64}$ 


\section{BREAST MILK CELLS}

As they contain viable leukocytes, colostrum and breast milk differ from most other secretions. The concentration of these leukocytes is higher in colostrum and decreases during the first month of lactation, meaning that mature milk contains just $2 \%$ of the colostrum cell concentration, resulting in approximately $10^{6}$ to $10^{9}$ cells $/ \mathrm{mL}$ in colostrum and $10^{5}$ cells $/ \mathrm{mL}$ in mature milk. Apart from epithelial cells, macrophages (32.6\%) and neutrophils (45.1\%) are present at a greater quantity in relation to lymphocytes $(21.3 \%)$, the latter represented mainly by $\mathrm{CD}^{+}$ $\mathrm{T}$ cells (83\%), almost equally distributed between $\mathrm{CD} 4^{+}$ and $\mathrm{CD} 8^{+},{ }^{65}$ as well as $\mathrm{T} \gamma \delta^{+}$cells $(11 \%), \mathrm{CD} 16^{+} \mathrm{NK}$ cells (3-4\%), and B cells (2\%).

More recent studies suggest that the number of macrophages in breast milk has been overestimated, as only a small proportion of these cells contains the characteristic surface markers of macrophages, such as CD $14 .{ }^{66} \mathrm{In}$ fact, macrophages may only represent $15 \%$ of breast milk leukocytes. It has been demonstrated that SIgA has the capacity to opsonize particles and microorganisms, enhancing phagocytic and microbicide activities through increased superoxide anion production by the phagocytes in the colostrum. ${ }^{67}$

Breast milk $\mathrm{T}$ cells differ both in relative abundance and quality when compared to the $T$ cells found in peripheral blood ${ }^{68}$ The largest proportion of TCD $8^{+} \mathrm{TCR} \gamma \delta^{+}(\mathrm{ex}-$ pressing L-selectin, integrin $\alpha 4 \beta 7$, MAdCAM- 1 ) compared with the blood suggests that these cytotoxic $\mathrm{T}$ cells $\left(\mathrm{CD} 8^{+}\right)$ carry out selective homing from the mucosal immune system to the mammary gland. ${ }^{68,69} \mathrm{CD}^{+} \mathrm{T}$ cells in the breast milk are also present in an activated state and express $\mathrm{CD} 45 \mathrm{RO}$, a surface protein associated with immunological memory. More than $70 \%$ of the B cells in breast milk are $\mathrm{CD} 27^{+} \mathrm{IgD}$ switched memory cells primed to secrete antibodies with overrepresentation of large-sized B cells, plasmablasts, and plasma cells, which do not express the complement receptor. ${ }^{12,70}$

\section{HUMAN MILK MICROBIOTA}

More recently, several studies have shown that colostrum and breast milk are continuous sources of commensal and potentially probiotic bacteria for the infant's intestine. This is an important finding given that intramammary breast milk has traditionally been considered sterile. In fact, human milk is a major source of bacteria for the intestine of infants, given that a baby that consumes approximately $800 \mathrm{~mL} /$ day of milk ingests approximately $1 \times 10^{5}$ and $1 \times 10^{7}$ bacteria per day. ${ }^{71}$ Several studies have shown that there is a transfer of bacterial strains through breastfeeding, at least for the genera Lactobacillus, Staphylococcus, Enterococcus, and Bifidobacterium, ${ }^{72}$ although recent techniques of microbial identification based on pyrosequencing of the 16S rDNA gene have enabled the identification of several other species (Table 2). ${ }^{73}$

It has been observed that the administration of strains of Lactobacillus from breast milk to 6-month old babies led to reductions of 46,27 and $30 \%$ in the frequency of gastrointestinal, upper respiratory tract and total number of infections, respectively. ${ }^{74}$

\section{BREAST MILK AND PROTECTION AGAINST INFECTIONS}

Several epidemiological and experimental studies have been conducted to investigate the effect of human milk against different organisms involved in respiratory and gastrointestinal infections. These studies have demonstrated that human milk has antibodies against Shigella, Salmonella typhimurium, Campylobacter, Vibrio cholerae, Haemophilus influenzae, Streptococcus pneumoniae, Bordetella pertussis, respiratory syncytial virus, HIV, and other pathogens. ${ }^{7,75}$

Epidemiological data indicate that exclusively breastfed children are better protected against a variety of infections ${ }^{76}$ and apparently also against celiac disease in childhood ${ }^{77}$ as well as allergies and asthma, ${ }^{78}$ although studies on the latter issue still show discrepant data. ${ }^{79,80}$ It is known that the risk of death from diarrhea can be reduced from 14 to 24 times in infants fed human milk, and that the frequency of diarrhea increases as the milk is replaced by other sources, until full weaning. ${ }^{81}$

This effect is illustrated in a study conducted in Brazil showing that exclusive breastfeeding reduces the risk of death from diarrhea by 14.2 times, whereas partial breastfeeding is associated with a reduction of 4.2 times, both compared to the group that was not breastfed. ${ }^{82}$

SIgA antibodies present in the colostrum and milk of Brazilian women have an important role in protecting against infections by enteropathogenic $E$. coli (EPEC). The first experiments demonstrated the strong capacity of colostrum (48 to 72 hours after delivery) and milk (from the $7^{\text {th }}, 30^{\text {th }}$ e $60^{\text {th }}$ days of lactation) samples from mothers in the city of São Paulo to inhibit in vitro EPEC adherence to HEp-2 cells (Figure 2) ${ }^{83} \mathrm{Next}$, it was demonstrated that SIgA was the primary mediator of bacterial inhibition, and that these antibodies alone, which are reactive with intimin, the main adhesin in EPEC, responsible for the binding of the bacteria to enterocytes, were able to strongly inhibit the adhesion of EPEC to the HEp-2 cells mentioned above. In turn, all samples of colostrum and milk from the mothers studied presented antibodies for 

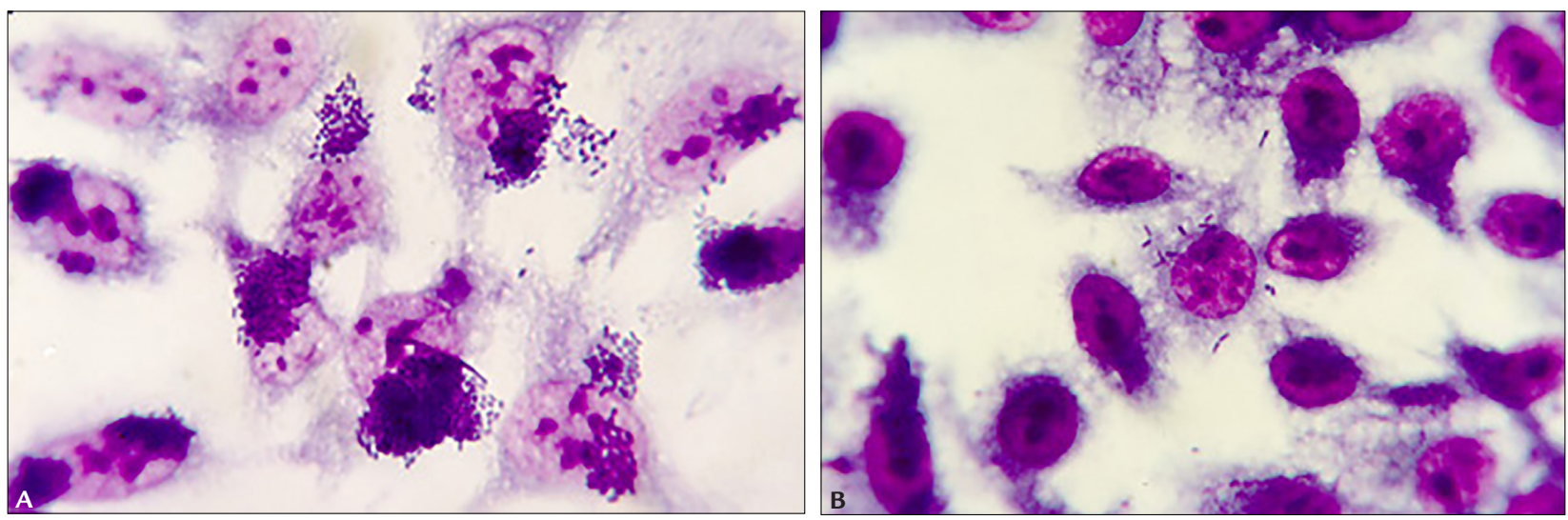

Figure 2 A. Photomicrograph of the appearance of the adherence of enteropathogenic E. coli (EPEC) on human epithelial cells in a culture of the HEp-2 cell lineage, where adhesion of bacteria can be observed in almost $100 \%$ of the cells in an adhesion pattern characteristic of EPEC called localized adherence, and (B) the inhibitory effect of the "pool" of human colostrum on EPEC adhesion to HEp-2 cells, where it can be noted that almost $100 \%$ of the HEp-2 cells are free of bacteria. 1,000 times magnification.

intimin and other virulence factors of EPEC. ${ }^{15,84-86} \mathrm{Simi}-$ lar data were found in samples of mothers of term newborns with low birth weight and premature babies. ${ }^{87}$

As a result of the concern for low birth weight newborns or premature infants, who often require banks of breast milk, the possibility of changing the biological properties of colostrum and milk was investigated after being subjected to the usual treatments of pasteurization, lyophilization, and exposure to microwaves. ${ }^{88}$ These treatments did not alter the ability to inhibit bacterial adhesion, although pasteurization partially reduced the total IgA level and the level of anti-EPEC antibodies. ${ }^{89}$ When neutralizing the virulence factors of EPEC, these antibodies protect the infant's intestine against colonization and infection, and may also protect children against the systemic effects of LPS by inhibiting the absorption of the bacterial endotoxins involved in septic shock. ${ }^{90}$

In a study conducted with a sample of colostrum from one parturient woman with IgA deficiency, inhibitory activity was observed both for adhesion of EPEC and invasion of enteroinvasive E. coli (EIEC) in HEp-2 cells, at levels equivalent to normal control colostra. Furthermore, a high level of SIgM has been described in this secretion, which could represent a compensatory phenomenon to the SIgA deficiency. ${ }^{91}$

The inhibitory activity on the adhesion of shiga-like toxin-producing E. coli (STEC), enteroaggregative E. coli (EAggEC), enterotoxigenic E. coli (ETEC), and the invasion of EIEC has been further demonstrated in other studies. ${ }^{92-95}$

The role of breast milk in the protection against rotavirus infection is still unclear, as in some cases a delay is observed in the development of the disease, while in others the infections are asymptomatic. ${ }^{96}$ However, a delay in the appearance of rotavirus in the feces has been reported when associated with high levels of SIgA antibodies in the milk. ${ }^{97}$

In relation to respiratory infections, studies investigating the protective ability of breast milk against otitis media have demonstrated effective protection against acute and prolonged infections. ${ }^{98-100}$ It is also suggested that breastfeeding may protect against upper respiratory tract infections, but this role still lacks confirmation. ${ }^{101} \mathrm{~A}$ study conducted in the United States, comparing the effects of exclusive breastfeeding for 4 and 6 months on the appearance of pneumonia and otitis revealed a reduction of these infections in the group that was breastfed for 6 months compared to the group breastfed for 4 months. ${ }^{102}$

\section{BREAST MILK AND PROTECTIVE EFFECT ON PREMATURE OR UNDERWEIGHT INFANTS}

Considering the importance of breastfeeding as an immune supplement for healthy term newborns, it is even more crucial in the case of prematurity. The main causes of morbidity, mortality, and sequelae in the long term in these children are sepsis, meningitis, and necrotizing enterocolitis (NEC), but there is evidence that breast milk oligosaccharides and antibodies can help protect against these diseases. ${ }^{39,103}$

One issue to be discussed is the daily amount of breast milk ingested and its effect on the incidence of infections. Two studies on premature newborns have addressed this issue. Furman et al. found that at least $50 \mathrm{~mL} / \mathrm{kg} /$ day of human milk were needed to show a decrease in the rate of sepsis in very low birth weight infants, ${ }^{104}$ while Schan- 
ler et al. demonstrated that children who received the same dose from birth to 90 days old or hospital discharge showed a reduction in both sepsis as well as NEC rates. ${ }^{105}$

\section{BREAST MILK AND LONG TERM PROTECTIVE EFFECT}

There are many recent studies investigating a possible role of breastfeeding on the risk of developing many common diseases in which inflammation plays a central role in pathogenesis. There is a wide variety of milk components that affect the development and function of the immune system and that could exert this effect, as has already been demonstrated for allergic diseases, some showing protection, others not. ${ }^{106,107}$

This protective effect in the long term can also be observed in epidemiological studies that suggest that human milk lowers the risk of development of autoimmune diseases such as type 1 and 2 diabetes mellitus, rheumatoid arthritis, celiac disease, ulcerative colitis, and Crohn's disease. ${ }^{4}$

Some studies indicate that breastfeeding has a protective effect against chronic vascular diseases, including hypertension, obesity and/or insulin resistance. ${ }^{108-110} \mathrm{~A}$ meta-analysis has shown that breastfeeding protects against childhood tumors such as acute lymphoblastic leukemia, Hodgkin's disease, and neuroblastoma. ${ }^{111}$

\section{Conclusion}

Several clinical studies confirm the beneficial effects of breastfeeding on the growth, development, and anti-infective defense from infancy to adulthood. Breastfeeding not only provides an ideal nutritional composition for the newborn but also represents an extraordinary immunological integration between the mother and the infant. The expansion of knowledge about the immunological composition of breast milk reinforces the importance of many components present even in small amounts in this secretion, which is a perfect food and a supplement with increasingly recognized immunological value.

\section{Resumo}

\section{Imunologia do leite materno}

$\mathrm{Na}$ fase crítica de imaturidade imunológica do recém-nascido, em especial do sistema imune de mucosas, o lactente recebe grandes quantidades de componentes bioativos através do colostro e do leite materno. O colostro é o reforço imunológico natural mais potente conhecido pela ciência. $\mathrm{O}$ aleitamento materno protege o lactente de infecções principalmente por meio dos anticorpos IgA secre- tores (IgAS), mas também por meio de vários outros fatores bioativos. É surpreendente que os fatores de defesa do leite humano ajam sem causar inflamação e alguns componentes são, de fato, anti-inflamatórios. A proteção contra infecções tem sido bem evidenciada durante a lactação, combatendo, por exemplo, diarreia aguda e prolongada, infecções do trato respiratório, incluindo otite média, infecção do trato urinário, sepse neonatal e enterocolite necrosante. O conteúdo imunológico do leite evolui ao longo do tempo: nas fases iniciais de lactação, IgAS, fatores anti-inflamatórios e, mais provavelmente, as células imunologicamente ativas provêm ajuda adicional para o sistema imune imaturo do neonato. Depois desse período, o leite materno continua a adaptar-se extraordinariamente à ontogenia infantil, às suas necessidades de proteção imune e nutricionais. Entende-se, portanto, a necessidade de se estimular o aleitamento materno pelo menos durante o primeiro semestre de vida, período em que a produção própria de IgA secretória é ainda pouco significativa.

Palavras-chave: leite humano, anticorpos IgA secretores, infecções, recém-nascido a termo, recém-nascido pré-termo.

\section{References}

1. Lewis DB, Wilson CB. Developmental immunology and role of host defenses in neonatal susceptibility to infection. In: Remington JS, Klein JO, Wilson $\mathrm{CB}$, Nizet V, Maldonado YA, editors. Infectious diseases of the fetus and newborn infant. 7.ed. Philadelphia: Saunders; 2011. p.83-169.

2. Hanson LA, Korotkova M, Lundin S, Håversen L, Silfverdal SA, MattsbyBaltzer I, et al. The transfer of immunity from mother to child. Ann N Y Acad Sci. 2003; 987:199-206.

3. Hosea Blewett HJ, Cicalo MC, Holland CD, Field CJ. The immunological components of human milk. Adv Food Nutr Res. 2008; 54:45-80.

4. Hanson LA. Symposium on 'Nutrition in early life: new horizons in a new century'. Session 1: Feeding and infant development. Breast-feeding and immune function. Proc Nutr Society. 2007; 66:384-96.

5. Morrow AL, Rangel JM. Human milk protection against infectious diarrhea: Implications for prevention and clinical care. Semin Pediatr Infect Dis. 2004; 15(4):221-8.

6. Hanson LA. Breastfeeding provides passive and likely long-lasting active immunity. Ann Allergy Asthma Immunol. 1998; 81(6):523-37.

7. Hanson LA, Korotkova M. The role of breastfeeding in prevention of neonatal infection. Semin Neonatol. 2002; 7(4):275-81.

8. Goldman AS, Thorpe LW, Goldblum RM, Hanson LA. Anti-inflammatory properties of human milk. Acta Paediatr Scand. 1986; 75(5):689-95.

9. Lepage P, Van de Perre P. The immune system of breast milk: antimicrobial and anti-inflammatory properties. Adv Exp Med Biol. 2012; 743:121-37.

10. Brandtzaeg P. The mucosal immune system and its integration with the mammary glands. J Pediatr. 2010; 156(2 Suppl):S8-15.

11. Brandtzaeg P, Kiyono H, Pabst R, Russell MW. Terminology: nomenclature of mucosa-associated lymphoid tissue. Mucosal Immunol. 2008; 1(1):31-7.

12. Carlsson B, Hanson LA. Immunologic effects of breast-feeding on the infant. In: Ogra P, Lamm ME, Strober W, McGhee JR, Bienestock J, editors. Handbook of Mucosal Immunology. London: Academic Press; 1994. p.653-66.

13. Johansen FE, Brandtzaeg P. Transcriptional regulation of the mucosal IgA system. Trends Immunol. 2004; 25(3):150-7.

14. Palmeira P, Costa-Carvalho BT, Arslanian C, Pontes GN, Nagao AT, CarneiroSampaio MM. Transfer of antibodies across the placenta and in breast milk from mothers on intravenous immunoglobulin. Pediatr Allergy Immunol. $2009 ; 20(6): 528-35$. 
15. Carbonare SB, Silva ML, Palmeira P, Carneiro-Sampaio MM. Human colostrum IgA antibodies reacting to enteropathogenic Escherichia coli antigens and their persistence in the faeces of a breastfed infant. J Diarrhoeal Dis Res. 1997; 15(2):53-8.

16. de Araújo AN, Giugliano LG. Lactoferrin and free secretory component of human milk inhibit the adhesion of enteropathogenic Escherichia coli to HeLa cells. BMC Microbiol. 2001; 1:25.

17. Bessler HC, de Oliveira IR, Giugliano LG. Human milk glycoproteins inhibit the adherence of Salmonella typhimurium to HeLa cells. Microbiol Immunol. 2006; 50(11):877-82.

18. Hammerschmidt S, Talay SR, Brandtzaeg P, Chhatwal GS. SpsA, a novel pneumococcal surface protein with specific binding to secretory immunoglobulin A and secretory component. Mol Microbiol. 1997; 25(6):1113-24.

19. Dallas SD, Rolfe RD. Binding of Clostridium difficile toxin A to human milk secretory component. J Med Microbiol. 1998; 47(10):879-88.

20. Chipman DM, Sharon N. Mechanism of lysozyme action. Science. 1969; 165(3892):454-65

21. Ellison RTJ, Giehl TJ. Killing of Gram-negative bacteria by lactoferrin and lysozyme. J Clin Invest. 1991; 88(4):1080-91.

22. Lee-Huang S, Huang PL, Sun Y, Huang PL, Kung HF, Blithe DL, et al. Lysozyme and RNases as anti-HIV components in beta-core preparations of human chorionic gonadotropin. Proc Natl Acad Sci U S A. 1999; 96(6):2678-81.

23. Houghton M, Santoso H, Soetjiningsih, Gracey M. Lactoferrin concentrations in the breast milk of Indonesian mothers. Paediatr Indones. 1985; 25(910):163-6.

24. Mattsby-Baltzer I, Roseanu A, Motas C, Elverfors J, Engberg I, Hanson LA. Lactoferrin or a fragment thereof inhibits the endotoxin-induced interleukin-6 response in human monocytic cells. Pediatr Res. 1996; 40(2):257-62.

25. Elass E, Masson M, Mazurier J, Legrand D. Lactoferrin inhibits the lipopolysaccharide-induced expression and proteoglycan-binding ability of interleukin-8 in human endothelial cells. Infect Immun. 2002; 70(4):1860-6.

26. Håversen LA, Baltzer L, Dolphin G, Hanson LA, Mattsby-Baltzer I. Antiinflammatory activities of human lactoferrin in acute dextran sulphateinduced colitis in mice. Scand J Immunol. 2003; 57(1):2-10.

27. Hashizume S, Kuroda K, Murakami H. Identification of lactoferrin as an essential growth factor for human lymphocytic cell lines in serum-free medium. Biochim Biophys Acta. 1983; 763(4):377-82.

28. Tomita M, Bellamy W, Takase M, Yamauchi K, Wakabayashi H, Kawase K. Potent antibacterial peptides generated by pepsin digestion of bovine lactoferrin. J Dairy Sci. 1991; 74(12):4137-42.

29. Steele WF, Morrison M. Antistreptococcal activity of lactoperoxidase. J Bacteriol. 1969; 97(2):635-9.

30. Björck L, Rosén CG, Marshall V, Reiter B. Antibacterial activity of lactoperoxidase system in milk against pseudomonas and other Gramnegative bacteria. Appl Microbiol. 1975; 30(2):199-204.

31. Lönnerdal B. Nutritional and physiologic significance of human milk proteins. Am J Clin Nutr. 2003; 77(6):1537S-43S

32. Pellegrini A, Thomas U, Bramaz N, Hunziker P, von Fellenberg R. Isolation and identification of three bactericidal domains in the bovine alphalactalbumin molecule. Biochim Biophys Acta. 1999; 1426(3):439-48.

33. Hallgren O, Aits S, Brest P, Gustafsson L, Mossberg AK, Wullt B, et al. Apoptosis and tumor cell death in response to HAMLET (human alpha-lactalbumin made lethal to tumor cells). Adv Exp Med Biol. 2008; 606:217-40.

34. Adkins Y, Lönnerdal B. Potential host-defense role of a human milk vitamin B-12-binding protein, haptocorrin, in the gastrointestinal tract of breastfed infants, as assessed with porcine haptocorrin in vitro. Am J Clin Nutr. 2003; 77(5):1234-40.

35. Vidal K, van den Broek P, Lorget F, Donnet-Hughes A. Osteoprotegerin in human milk: A potential role in the regulation of bone metabolism and immune development. Pediatr Res. 2004; 55(6):1001-8.

36. Vidal K, Serrant P, Schlosser B, van den Broek P, Lorget F, Donnet-Hughes A. Osteoprotegerin production by human intestinal epithelial cells: a potential regulator of mucosal immune responses. Am J Physiol Gastrointest Liver Physiol. 2004; 287(4):G836-G44.

37. Blewett HJH, Cicalo MC, Holland CD, Field CJ. The immunological components of human milk. Adv Food Nutr. 2008; 54:45-80.

38. Labéta MO, Vidal K, Nores JE, Arias M, Vita N, Morgan BP, et al. Innate recognition of bacteria in human milk is mediated by a milk-derived highly expressed pattern recognition receptor, soluble CD14. J Exp Med. 2000; 191(10):1807-12
39. Lawrence RM, Pane CA. Human breast milk: current concepts of immunology and infectious diseases. Curr Probl Pediatr Adolesc Health Care. 2007; 37(1):7-36

40. Skansén-Saphir U, Lindfors A, Andersson U. Cytokine production in mononuclear cells of human milk studied at the single cell level. Pediatr Res. 1993; 34(2):213-6.

41. Hara T, Irie K, Saito S, Ichijo M, Yamada M, Yanai N, et al. Identification of macrophage colony-stimulating factor in human milk and mammary epithelial cells. Pediatr Res. 1995(4 Pt 1); 37:437-43.

42. Gilmore WS, McKelvey-Martin VJ, Rutherford S, Strain JJ, Loane P, Kell M, et al. Human milk contains granulocyte colony stimulating factor. Eur J Clin Nutr. 1994; 48(3):222-4.

43. Garofalo R. Cytokines in human milk. J Pediatr. 2010; 156(2 Suppl):S36-40

44. Basolo F, Fiore L, Fontanini G, Giulio P, Simonetta C, Falcone V, et al. Expression of response to interleukin 6 (IL6) in human mammary tumors. Cancer Res. 1996; 56(13):3118-22.

45. Verhasselt V. Neonatal tolerance under breastfeeding influence: the presence of allergen and transforming growth factor-b in breast milk protects the progeny from allergic asthma. J Pediatr. 2010; 156(2 Suppl):S16-20.

46. Keeney SE, Schmalstieg FC, Palkowetz KH, Rudloff E, Le BM, Goldman AS Activated neutrophils and neutrophil activators in human milk: increased expression of CD11b and decreased expression of L-selectin. J Leukoc Biol. 1993; 54(2):97-104

47. Ebert E. IL-8, RANTES, and GRO are chemotactic for intraepithelial lymphocytes (IEL). Gastroenterology. 1995; 108(4):A813.

48. Cocchi F, DeVico AL, Garzino-Demo A, Arya SK, Gallo RC, Lusso P. Identification of RANTES, MIP-1 alpha, and MIP-1 beta as the major HIV suppressive factors produced by CD8+ T cells. Science. 1995; 270(5243):1811-5.

49. German JB, Dillard CJ. Composition, structure and absorption of milk lipids: a source of energy, fat-soluble nutrients and bioactive molecules. Crit Rev Food Sci Nutr. 2006; 46(1):57-92.

50. Isaacs CE. The antimicrobial function of milk lipids. Adv Nutr Res. 2001; 10:271-85

51. Thormar H, Isaacs CE, Brown HR, Barshatzky MR, Pessolano T. Inactivation of enveloped viruses and killing of cells by fatty acids and monoglycerides. Antimicrob Agents Chemother. 1987; 31(1):27-31.

52. Welsh JK, Skurrie IJ, May JT. Use of Semliki forest virus to identify lipidmediated antiviral activity and anti-alphavirus immunoglobulin $\mathrm{A}$ in human milk. Infect Immun. 1978; 19(2):395-401.

53. Schroten H, Hanisch FG, Plogmann R, Hacker J, Uhlenbruck G, NobisBosch R, et al. Inhibition of adhesion of S-fimbriated Escherichia coli to buccal epithelial cells by human milk fat globule membrane components: a novel aspect of the protective function of mucins in the nonimmunoglobulin fraction. Infect Immun. 1992; 60(7):2893-9.

54. Kvistgaard AL, Pallesen LT, Arias CF, López S, Petersen TE, Heegaard CW, et al. Inhibitory effects of human and bovine milk constituents on rotavirus infections. J Dairy Sci. 2004; 87(12):4088-96

55. Pickering LK, Granoff DM, Erickson JR, Masor ML, Cordle CT, Schaller JP, et al. Modulation of the immune system by human milk and infant formula containing nucleotides. Pediatrics. 1998; 101(2):242-9.

56. Erney RM, Malone WT, Skelding MB, Marcon AA, Kleman-Leyer KM, O'Ryan $\mathrm{ML}$, et al. Variability of human milk neutral oligosaccharides in a diverse population. J Pediatr Gastroenterol Nutr. 2000; 30(2):181-92.

57. Newburg DS. Are all human milks created equal? Variation in human milk oligosaccharides. J Pediatr Gastroenterol Nutr. 2000; 30(2):131-3.

58. Kleesen B, Bunke H, Tovar K, Noack J, Sawatzki G. Influence of two infant formulas and human milk on the development of the fecal flora in newborn infants. Acta Paediatr. 1995; 84(12):1347-56

59. Newburg DS. Do the binding properties of oligosaccharides in milk protect human infants from gastrointestinal bacteria? J Nutr. 1997; 127(5 Suppl): 980S-4S

60. Romeu-Nadal M, Morera-Pons S, Castellote AI, López-Sabater MC. Determination of gamma- and alpha-tocopherols in human milk by a direct high performance liquid chromatographic method with UV-vis detection and comparison with evaporative light scattering detection. J Chromatogr A. $2006 ; 1114(1): 132-7$

61. Sakurai T, Furukawa M, Asoh M, Kanno T, Kojima T, Yonekubo A. Fatsoluble and water-soluble vitamin contents of breast milk from Japanese women. J Nutr Sci Vitaminol (Tokyo). 2005; 51(4):239-47.

62. Darragh AJ, Moughan PJ. The amino acid composition of human milk corrected for amino acid digestibility. Br J Nutr. 1998; 80(1):25-34 
63. Friel JK, Martin SM, Langdon M, Herzberg GR, Buettner GR. Milk from mothers of both premature and full-term infants provides better antioxidant protection than does infant formula. Pediatr Res. 2002; 51(5):612-8.

64. Grazioso CF, Buescher ES. Inhibition of neutrophil function by human milk. Cell Immunol. 1996; 168(2):125-32.

65. Barros MD, Carneiro-Sampaio MMS. Milk composition of low birth weight infant mothers. Acta Paediatr Scand. 1984; 73:693-5.

66. Fan Y, Chong YS, Choolani MA, Cregan MD, Chan JK. Unravelling the mystery of stem/progenitor cells in human breast milk. PLoS One. 2010; 5(12):e14421.

67. Honorio-França AC, Isaac L, Trabulsi LR, Carneiro-Sampaio MMS. Colostral mononuclear phagocytes are able to kill enteropathogenic Escherichia coli (EPEC) opsonized by colostral IgA. Scand J Immunol. 1997; 46(1):59-66.

68. Sabbaj S, Ghosh MK, Edwards BH, Leeth R, Decker WD, Goepfert PA, et al. Breast milk-derived antigen-specific CD8+ T cells: An extra-lymphoid effector memory cell population in humans. J Immunol. 2005; 174(5):2951-6.

69. Wirt DP, Adkins LT, Palkowetz KH, Schmalstieg FC, Goldman AS. Activated and memory T lymphocytes in human milk. Cytometry. 1992; 13(3):282-90.

70. Tuaillon E, Valea D, Becquart P, Al Tabaa Y, Meda N, Bollore K, et al. Human milk-derived B cells: a highly activated switched memory cell population primed to secrete antibodies. J Immunol. 2009; 182(11):7155-62.

71. Heikkilä MP, Saris PEJ. Inhibition of Staphylococcus aureus by the commensal bacteria of human milk. J Appl Microbiol. 2003; 95(3):471-8.

72. Martín V, Maldonado-Barragán A, Moles L, Rodríguez-Baños M, Del Campo R, Fernández L, et al. Sharing of bacterial strains between breast milk and infant feces. J Hum Lact. 2012; 28(1):36-44.

73. Fernández L, Langa S, Martín V, Maldonado A, Jiménez E, Martín R, et al. The human milk microbiota: origin and potential roles in health and disease. Pharmacol Res. 2013; 69(1):1-10.

74. Maldonado J, Cañabate F, Sempere L, Vela F, Sánchez AR, Narbona E, et al. Human milk probiotic Lactobacillus fermentum CECT5716 reduces the incidence of gastrointestinal and upper respiratory tract infections in infants. J Pediatr Gastroenterol Nutr. 2012; 54(1):55-61

75. Quinello C, Quintilio W, Carneiro-Sampaio M, Palmeira P. Passive acquisition of protective antibodies reactive with Bordetella pertussis in newborns via placental transfer and breast-feeding. Scand J Immunol. 2010; 72(1):66-73

76. Wright AL, Bauer M, Naylor A, Sutcliffe E, Clark L. Increasing breast-feeding rates to reduce infant illness at the community level. Pediatrics. 1998; 101(5):837-44.

77. Ivarsson A, Hernell O, Stenlund H, Persson LA. Breast-feeding protects against celiac disease. Am J Clin Nutr. 2002; 75(5):914-21.

78. Oddy WH, Holt PG, Sly PD, Read AW, Landau LI, Stanley FJ, et al. Association between breast-feeding and asthma in 6-year-old children: findings of a prospective birth cohort study. BMJ. 1999; 319(7213):815-9.

79. Oddy WH, Peat JK, de Klerk NH. Maternal asthma, infant feeding, and the risk of asthma in childhood. J Allergy Clin Immunol. 2002; 110(1):65-7.

80. Sears MR, Greene JM, Willan AR, Taylor DR, Flannery EM, Cowan JO, et al. Longterm relation between breast-feeding and development of atopy and asthma in children and young adults: a longitudinal study. Lancet. 2002;360(9337):901-7.

81. Kaiser AM. A warm chain for breast-feeding. Lancet. 1994; 344(8932):1239-41.

82. Victora CG, Smith PG, Vaughan JP, Nobre LC, Lombardi C, Teixeira AM, et al. Evidence for protection by breast-feeding against infant deaths from infectious diseases in Brazil. Lancet. 1987; 2(8554):319-22

83. Carneiro-Sampaio MMS, Silva MLM, Carbonare SB, Palmeira P, Delneri MT, Honório AC, et al. Breast-feeding protection against enteropathogenic Escherichia coli. Rev Microbiol. 1996; 27:120-5.

84. Adu-Bobie J, Trabulsi LR, Carneiro-Sampaio MMS, Dougan G, Frankel G. Identification of immunodominant region within the C-terminal cell binding domain of intimin alpha and beta from enteropathogenic Escherichia coli. Infect Immun. 1998; 66(12):5643-9.

85. Loureiro I, Frankel G, Adu-Bobie J, Dougan G, Trabulsi LR, Carneiro-Sampaio MMS. Human colostrum contains IgA antibodies reactive to enteropathogenic Escherichia coli virulence-associated proteins: Intimin, BfpA, EspA and EspB. J Pediatr Gastroenterol Nutr. 1998; 27(2):166-71.

86. Sanchez MI, Keller R, Hartland EL, Figueredo DMM, Batchelor M, Martinez $\mathrm{MB}$, et al. Human colostrum and serum contain antibodies reactive to the intimin-binding region of the enteropathogenic Escherichia coli. J Pediatr Gastroenterol Nutr. 2000; 30(1):73-7.

87. Delneri MT, Carbonare SB, Palmeira P, Silva MLM, Carneiro-Sampaio MMS. Inhibition of enteropathogenic Escherichia coli to HEp-2 cells by colostrum and milk from mothers delivering low-birth-weight neonates. Eur J Pediatr. $1997 ; 156: 493-8$.
88. Quan R, Yang C, Rubinstein S, Lewinston NJ, Sunshine P, Stevenson DK, et al. Effects of microwave radiation on anti-infective factors in human milk. Pediatrics. 1992; 89(4 Pt 1):667-9.

89. Carbonare SB, Palmeira P, Silva MLM, Carneiro-Sampaio MMS. Effect of microwave radiation, pasteurization and lyophilization on the ability of human milk to inhibit Escherichia coli adherence to HEp-2 cells. J Diarrhoeal Dis Res. 1996; 14(2):90-4.

90. Nagao AT, Martinez CC, Takano OA, Vieira VS, Costa-Carvalho BT, CarneiroSampaio MMS. Placental transfer of IgG and IgG subclass antibodies antipurified Escherichia coli LPS O16, O6 and O111. Scand J Immunol. 1998; 47(6):609-14

91. Barros MD, Porto MHO, Leser PG, Grumach AS, Carneiro-Sampaio MMS Study of colostrum of a patient with Selective IgA deficiency. Allergol Immunopathol (Madr). 1985; 13(4):331-4.

92. Palmeira P, Carbonare SB, Amaral JA, De Franco MT, Carneiro-Sampaio MMS. Colostrum from healthy Brazilian women inhibits adhesion and contains IgA antibodies reactive with Shiga toxin-producing Escherichia coli. Eur J Pediatr. 2005; 164(1):37-43

93. Fernandes RM, Carbonare SB, Carneiro-Sampaio MMS, Trabulsi LR. Inhibition of enteroaggregative Escherichia coli adhesion to HEp-2 cells by secretory immunoglobulin A from human colostrum. Pediatr Infect Dis J $2001 ; 20(7): 672-8$.

94. Corrêa S, Palmeira P, Carneiro-Sampaio MMS, Nishimura LS, Guth BEC. Human colostrum contains IgA antibodies reactive to colonization factors I and II of enterotoxigenic Escherichia coli. FEMS Immunol Med Microbiol. 2006; 47(2):199-206.

95. Carbonare SB, Silva MLM, Trabulsi LR, Carneiro-Sampaio MMS. Inhibition of HEp-2 cell invasion by enteroinvasive Escherichia coli by human colostrum IgA. Int Arch Allergy Immunol. 1995; 108(2):113-8.

96. Clemens J, Rao M, Ahmed F, Ward R, Huda S, Chakraborty J, et al. Breastfeeding and the risk of life-threatening rotavirus diarrhea: prevention or postponement? Pediatrics. 1993; 92(5):680-5.

97. Espinoza F, Paniagua M, Hallander H, Svensson L, Strannegård O. Rotavirus infections in young Nicaraguan children. Pediatr Infect Dis J. 1997; 16(6):564-71.

98. Cushing AH, Samet JM, Lambert WE, Skipper BJ, Hunt WC, Young SA, et al. Breastfeeding reduces risk of respiratory illness in infants. Am J Epidemiol. 1998; 147(9):863-70.

99. Dewey KG, Heinig MJ, Nommsen-Rivers LA. Differences in morbidity between breast-fed and formula-fed infants. J Pediatr. 1995; $126(5$ Pt 1):696-702.

100. Duncan B, Ey J, Holberg CJ, Wright AL, Martinez FD, Taussig LM. Exclusive breast-feeding for at least 4 months protects against otitis media. Pediatrics. 1993; 91(5):867-72.

101. Howie PW, Forsyth JS, Ogston SA, Clark A, Florey CD. Protective effect of breast feeding against infection. BMJ. 1990; 300(6716):11-6.

102. Chantry CJ, Howard CR, Auinger P. Full breastfeeding duration and associated decrease in respiratory tract infection in US children. Pediatrics. 2006; 117(2):425-32.

103. Schnabl KL, Van Aerde JE, Thomson ABR, Clandinin MT. Necrotizing enterocolitis: a multifactorial disease with no cure. World J Gastroenterol. 2008; 14(14):2142-61

104. Furman L, Taylor G, Minich N, Hack M. The effect of maternal milk on neonatal morbidity of very low-birth-weight infants. Arch Pediatr Adolesc Med. 2003; 157(1):66-71.

105. Schanler RJ, Lau C, Hurst NM, Smith EO. Randomized trial of donor human milk versus preterm formula as substitutes for mothers' own milk in the feeding of extremely premature infants. Pediatrics. 2005; 116(2):400-6.

106. Saarinen UM, Kajosaari M. Breastfeeding as prophylaxis against atopic disease: prospective follow-up study until 17 years old. Lancet. 1995; 346(8982):1065-9.

107. Van Asperen PP, Kemp AS, Mellis CM. Relationship of diet in the development of atopy in infancy. Clin Allergy. 1984; 14(6):525-32.

108. Singhal A, Cole TJ, Fewtrell M, Lucas A. Breast milk feeding and lipoprotein profile in adolescents born preterm: follow-up of a prospective randomised study. Lancet. 2004; 363(9421):1571-8

109. Singhal A, Lucas A. Early origins of cardiovascular disease: is there a unifying hypothesis? Lancet. 2004; 363(9421):1642-5.

110. Martin RM, Gunnell D, Smith GD. Breastfeeding in infancy and blood pressure in later life: systematic review and meta-analysis. Am J Epidemiol. $2005 ; 161(1): 15-26$

111. Martin RM, Gunnell D, Owen CG, Smith GD. Breastfeeding and childhood cancer: a systematic review with meta-analysis. Int J Cancer. 2005; 117(6):1020-31. 